\title{
Исследование коэволюционных процессов в системе паразит-хозяин на примере видов рода Mycobacterium sp.
}

Бондаренко Т.А.*, Бородулин А.В., Борунова В.В., Луданный Р.И.

Центральный исследовательский институт эпидемиологии Роспотребнадзора, Москва, Россия

*e-mail: nikkybondarenko@yandex.ru

Key words: туберкулез, геномика, коэволюция

Мотивация и иель: В процессе коэволюции, путем адаптивных генетических перестроек, происходила специализированная адаптация микобактерий в системе паразит-хозяин, обеспечивая селективное преимущество патогенным видам. В связи с этим, целью нашего исследования является сравнительный молекулярно-генетический анализ полногеномных нуклеотидных последовательностей патогенных и условно-патогенных видов микобактерий, позволяя выявить генетическую значимость определенных генов, играющих ключевую роль в коэволюционных процессах.

Meтоды $и$ алгоритмы: Для сравнительного анализа нами были отобраны пять основных представителей туберкулезных (M. tuberculosis, M. avium, M. bovis) и нетуберкулезных (M. kansasi, M. smegmatis) видов микобактерий, полногеномные последовательности которых, ранее были депонированы в базе данных NCBI и использованы нами в последующем биоинформатическом анализе. Для определения GC-состава, расчетов индексов нуклеотидной парной идентичности и генетических дистанций использовалась программа GENEIOUS (ver. 7.0.9.). В связи с тем что не все геномы были аннотированы, нами была проделана автоматическая аннотация некоторых последовательностей с использованием программы Blast2GO (ver. 5.1). В связи с низким индексом идентичности геномов было принято решение рассчитать время дивергенции с помощью пакета программ MEGA(ver. 10.0.5), сопоставив его с временем дивергенции хозяина.

Результаты: Сравнительный анализ показал, что размер генома уменьшался в направлении от: не туберкулезных (M. smegmatis - 6,9 kb; M. kansasi - 6,5kb; M. avium-5kb) к туберкулезным видам (M. tuberculosis - 4,5 kb; M. bovis - 4,3 kb). Было обнаружено, что показатель генетической идентичности между анализируемыми видами варьировал от 1,4 до $8,3 \%$, в зависимости от выбора референтной последовательности. В связи с этим, для последующего анализа были использованы только кодирующие участки генома микобактерий. Было показано, что уровень идентичности в этих участках варьирует в пределах 81.7-90.7\% при покрытии 22-43\%. Эти данные не смогли ответить на вопрос, какие участки ответственны за патогенные свойства микобактерий. Данная работа предполагает в дальнейшем поиск ортологичных генов, которые могли быть утрачены в процессе приобретения микобактериямии патогенных свойств. 